\title{
Pengembangan Interpretasi Wisata Budaya Guna Mendukung Program Pelestarian Tapak Arkeologi
}

\author{
LURY SEVITA YUSIANA ${ }^{\star *}$, NI NYOMAN ARI MAYADEWI²
}

1. Program Studi Arsitektur Pertamanan, Fakultas Pertanian, Universitas Udayana Gedung Agrokompleks Lt. 2 Wing Barat, Jl. PB Sudirman Denpasar 80232, Indonesia

2. Program Studi Agroekoteknologi, Fakultas Pertanian Universitas Udayana

Gedung Agrokompleks Lt. 2, JI.PB Sudirman Denpasar 80232, Indonesia

*E-mail: Iury.yusiana@unud.ac.id

\section{ABSTRACT \\ Cultural Tourism Interpretation Development For Supporting Archeological Site In Preservation Program}

The development of the archaeological site into a tourist site resulting in the reduction or even loss of the values of the cultural heritage of archaeological objects and the archaeological site. However, the use for tourism can provide economic opportunities to the society and archaeological site preservation. Consequently, there are need some plan that can provide a variety of benefits and economic opportunities and remain to preserve their cultural values. The research aims were to study a variety of solutions and stages for the development of the site for tourism and archaeological interpretation. By looking at the physical, social, cultural, and visual conditions of the site were able to present the potential for tourism development. Analysis and synthesis methods were done to address the various challenges in developing the site. The results of the study was a site plan and a set of development program of the site with interpretation of education-based tourism as a solution for the preservation for the archaeological site.

Keywords : archeology site, cultural tourism, interpretation base on education, preservation program

\section{Pendahuluan}

Tapak arkeologi merupakan warisan budaya yang harus dilestarikan karena dapat memberikan pemahaman tentang kehidupan dan budaya masyarakat di masa itu. Pengembangan tapak arkeologi menjadi kawasan wisata menyebabkan tingginya jumlah pengunjung. Akan tetapi, berbagai kegiatan yang dilakukan pengunjung dapat menurunkan nilai benda atau tapak arkeologi itu sendiri. Hal ini menjadi tidak sejalan dengan pelestarian tapak arkeologi. Perencanaan yang sangat baik dalam mengembangkan dan memanfaatkan tapak arkeologi diperlukan untuk dapat meminimalisasi kerusakan akibat pemanfaatan tersebut. Pemahaman yang sangat baik 
mengenai tapak arkeologi perlu ditingkatkan melalui program interpretasi. Interpretasi merupakan suatu bentuk penyajian informasi kreatif untuk memberi arti dan pengertian pada wisatawan akan keberadaan, sejarah, dan kepentingan dari suatu sumber daya wisata dan berbagai obyek yang terkait dengan sumber daya tersebut (Nurisyah dan Damayanti, 2006). Penelitian ini bertujuan untuk merencanakan lansekap wisata pada tapak arkeologi guna mendukung kegiatan pelestarian cagar budaya dan merencanakan program interpretasi wisata tapak arkeologi yang bersifat edukatif.

\section{Metode}

Penelitian dilaksanakan pada Mei hingga Oktober 2015 dengan mengambil studi kasus pada tapak Candi Gunung Kawi, Tampaksiring, Bali. Lokasi ini dipilih karena merupakan salah satu situs cagar budaya di Bali yang dikembangkan sebagai destinasi wisata dengan jumlah pengunjung yang semakin meningkat.

Penelitian ini merupakan kajian dengan metode deskriptif kualitatif melalui pendekatan mengurai permasalahan yang terjadi pada pengembangan tapak arkeologi serta solusi bagi pengelolaan tapak arkeologi untuk pengembangan wisata dan pelestarian lansekap budaya (Gambar 1).

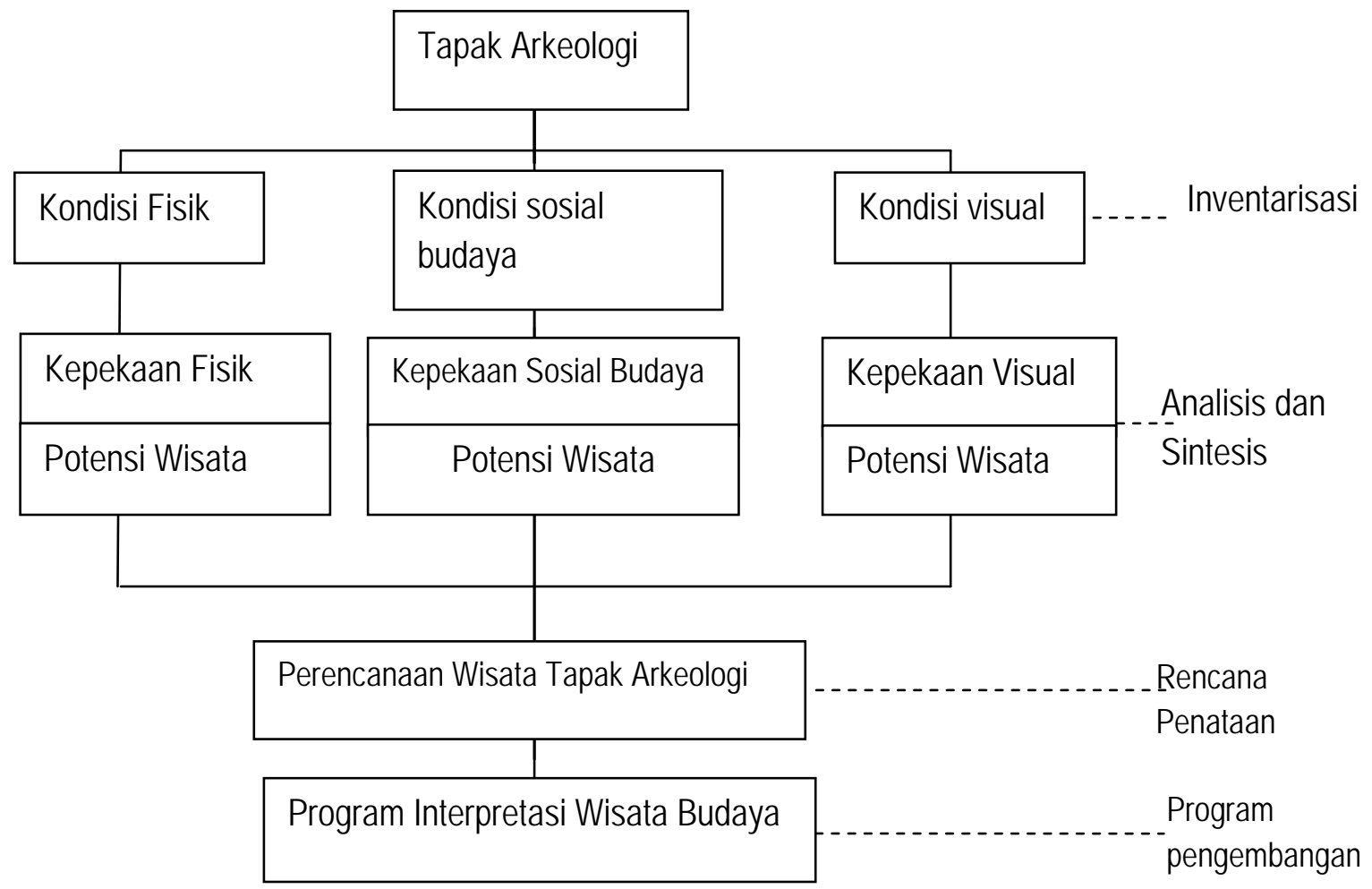

Gambar 1. Skema Tahapan Penelitian

\section{Hasil dan Pembahasan}

\subsection{Kondisi dan Kepekaan Tapak Arkeologi}

Kondisi dan kepekaan tapak arkeologi dilihat melalui 3 aspek, yaitu aspek fisik, aspek sosial budaya, dan aspek visual. Kondisi dan kepekaan tapak dapat menjadi potensi dan dapat juga menjadi faktor pembatas dalam pengembangannya. 


\subsubsection{Kondisi dan Kepekaan Fisik}

Kondisi dan kepekaan fisik tapak sangat mempengaruhi keberlangsungan kegiatan wisata dan daya dukung tapak. Kondisi dan kepekaan fisik meliputi tanah, topografi, iklim, hidrologi, vegetasi, satwa, dan benda arkeologi. Tanah yang subur memberi kemudahan bagi penataan vegetasi, sedangkan tanah yang kurang subur memerlukan teknologi dalam budidaya tanaman. Tapak Candi Gunung Kawi memiliki tanah yang subur karena tersusun atas batuan yang berasal dari lafa dan endapan lahar Buyan, Bratan, dan Batur.

Topografi tapak bergelombang dan berada pada ketinggian 496 mdpl (BPS Kabupaten Gianyar, 2014). Topografi datar dapat dimanfaatkan untuk berbagai kegiatan akan tetapi cenderung monoton, sedangkan topografi bergelombang dan curam memiliki daya tarik visual yang tinggi dan memerlukan rekayasa tapak dalam penempatan fasilitas wisata. Topografi curam juga memerlukan pengaman pada jalur jalan setapak atau dinding pengaman untuk menahan tanah yang berpotensi longsor.

Iklim merupakan faktor penentu kenyamanan pengunjung yang terdiri atas suhu, curah hujan, kelembaban, kecepatan angin, dan intensitas cahaya matahari. Suhu mempengaruhi kenyamanan pengunjung, karena aktivitas wisata memerlukan suhu yang nyaman untuk manusia. Suhu pada tapak Candi Gunung Kawi cukup nyaman, yaitu berkisar antara $23^{\circ}$ - 290 C (BPS Kabupaten Gianyar, 2014). Lebih lanjut diungkapkan curah hujan di tapak adalah 2258 mm pada tahun 2013 dan turun pada siang hingga menjelang sore hari. Curah hujan dengan intensitas ringan hingga sedang masih memungkinkan untuk aktivitas pengunjung ruang luar. Sedangkan intensitas hujan yang lebat menyulitkan pengunjung untuk beraktivitas. Lebih detil, hidrologi juga diperhatikan. Aliran air hujan, daerah potensi tergenang, dan daerah resapan air perlu mendapatkan perhatian, sehingga dapat disusun kriteria pemilihan tapak untuk penggunaan tertentu (Chiara\&Koppelman, 1978). Kelembaban pada tapak mencapai 82\% dan tergolong tinggi, sehingga dapat mengurangi kenyamanan pengunjung untuk beraktivitas. Intensitas cahaya tidak terlalu tinggi karena berada dilembah dan terhalang oleh dinding tebing. Arah dan kecepatan angin menjadi faktor yang dapat direkayasa untuk mendukung aktivitas pengunjung. Pada tapak arah dan kecepatan angin stabil karena posisinya pada lembah.

Vegetasi yang ditata pada lokasi wisata disesuaikan dengan fungsi dari desain penataan vegetasi. Fungsi vegetasi diantaranya sebagai peneduh, pengarah, pembatas, penghalang pandangan, pengontrol angin, pereduksi cahaya, arsitektural, dan estetika. Inventarisasi vegetasi pada tapak pengembangan diperlukan untuk mempertahankan vegetasi asli dan meminimalkan vegetasi introduksi guna mempertahankan ekologi tapak. Demikian juga halnya dengan satwa lokal. Satwa lokal tersebut dapat dikembangkan menjadi salah satu atraksi wisata tapak sehingga melestarikan satwa lokal dengan tetap menjaga lingkungan habitat asli satwa. Vegetasi dan satwa lokal dengan ekosistem tepi sungai mendominasi tapak ini, karena masih belum sepenuhnya dikembangkan.

Benda-benda arkeologi merupakan faktor kunci dari pengembangan tapak arkeologi untuk tujuan wisata. Benda arkeologi merupakan atraksi utama wisata arkeologi, sedangkan situs arkeologi merupakan daerah tujuan wisata. Situs arkeologi memuat benda, bangunan, dan juga struktur. Situs arkeologi yang memiliki nilai, sejarah, informasi, 
dan kearifan lokal ditetapkan sebagai situs cagar budaya mencakup benda, bangunan dan struktur yang ada didalamnya juga ditetapkan sebagai cagar budaya (Laksmi et al, 2011). Berdasarkan Undang-undang No.11 Tahun 2010, benda cagar budaya berupa benda bergerak dan tidak bergerak, bangunan cagar budaya merupakan susunan binaan yang terbuat dari benda alam atau benda buatan manusia untuk memenuhi kebutuhan ruang berdinding dan/atau tidak berdinding, dan beratap, sedangkan struktur cagar budaya merupakan hasil kegiatan manusia atau bukti kejadian pada masa lalu. Pada tapak Candi Gunung Kawi didominasi oleh Candi Tebing dan Ceruk Pertapaan. Tapak memiliki 10 candi tebing, gapura candi, peripih dan batu segi empat, serta beberapa ceruk pertapaan .

\subsubsection{Kondisi dan Kepekaan Sosial}

Kondisi Sosial dan kepekaan sosial meliputi penduduk, lembaga kemasyarakatan, sistem budaya, dan kearifan lokal. Penduduk merupakan sumber daya manusia sebagai pelaku wisata. Aktivitas sehari-hari, kegiatan ekonomi dan kegiatan religi masyarakat dapat dijadikan sebagai atraksi wisata. Pada tapak penelitian, penduduk usia produktif memiliki jumlah terbanyak yaitu 31450 jiwa (BPS Kabupaten Gianyar, 2014), sehingga pengembangan wisata dapat diarahkan pada pemberdayaan masyarakat lokal dengan memberi peluang usaha dan peluang ekonomi bidang pariwisata yang besar. Produk kreatif hasil karya masyarakat lokal digunakan sebagai souvenir dalam pengembangan ekonomi kreatif masyarakat. Kegiatan religi seperti kegiatan persembahyangan setiap hari maupun hari besar keagamaan menjadi daya tarik bagi wisatawan. Lembaga kemasyarakatan mampu berfungsi sebagai pengelola dalam pengembangan wisata berbasis masyarakat. Masyarakat Bali mengenal desa dinas dan desa adat sebagai pengelola desa. Desa dinas menangani administrasi pemerintahan, sedangkan desa adat menangani urusan agama dan adat (Toha, 2011). Pengembangan wisata di tapak hendaknya dilakukan melalui sosialisasi terhadap desa dinas dan desa adat. Regulasi terkait pemerintah membutuhkan kontribusi desa dinas, sedangkan pendekatan terhadap masyarakat desa membutuhkan peran desa adat. Kedua lembaga ini haruslah bersinergi dalam pengelolaan wisata. Pengelolaan wisata dan regulasi yang berkaitan dengan administrasi pemerintah pusat akan dikelola oleh desa dinas. Pengelolaan wisata terkait adat beserta regulasinya akan diatur oleh desa adat. Sistem pemerintahan yang unik ini mampu menjadi daya tarik wisata.

Sistem budaya menjadi landasan dalam pengembangan wisata. Sistem budaya erat kaitannya dengan kehidupan masyarakat sehari-hari yang mampu menjadi daya tarik wisata. Bali menggunakan landasan dan konsep tri hita karana dalam berbagai lini kehidupan. Tri hita karana bermakna hubungan yang harmonis antara manusia dengan Tuhan, alam dan sesama manusia. Aplikasi konsepsi tri hita karana dapat dilihat mulai dari sistem kelembagaan hingga sistem pertanian. Selain itu, tri mandala merupakan konsep tata ruang yang membagi wilayah berdasarkan utama-mandala, madya-mandala dan kanista-mandala. Utama-mandala adalah ruang suci yang ditujukan bagi kegiatan keagamaan, seperti tempat pemujaan. Madya-mandala adalah ruang yang difungskan bagi kegiatan manusia, seperti tempat tinggal manusia. Sedangkan kanista-mandala merupakan ruang yang digunakan untuk kegiatan nista atau yang kurang suci, seperti 
kebun. Tapak Candi Gunung Kawi merupakan tapak arkeologi yang disucikan keberadaannya oleh masyarakat Bali sehingga dalam pengembangan kegiatan wisata hendaknya memperhatikan kedua konsep ini, baik dalam penataan ruang maupun kegiatan wisata.

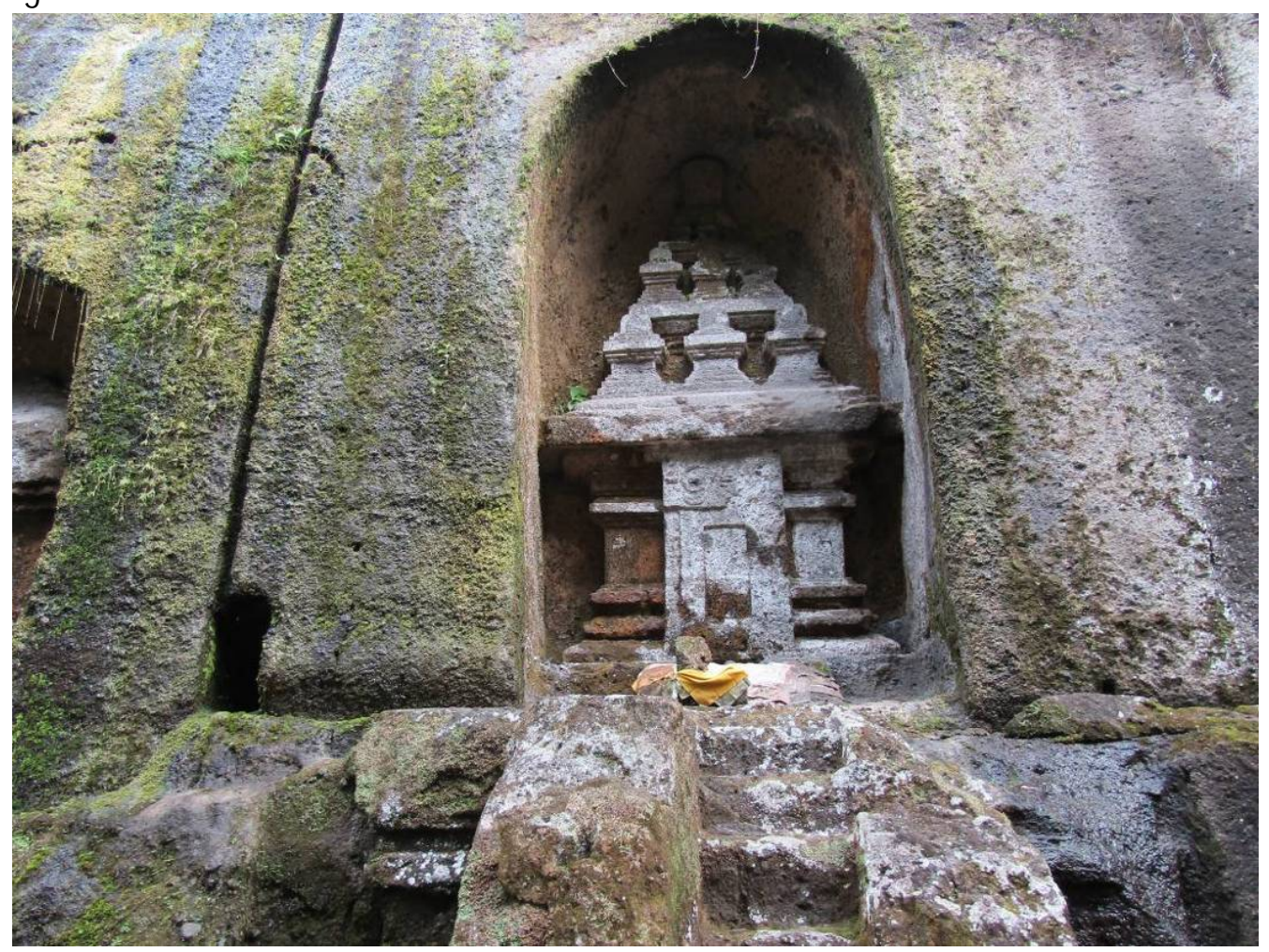

Gambar 2. Pahatan Saluran Air Di Samping Candi Tebing Sebagai Bentuk Kearifan Lokal Dalam Menjaga Kelestarian Candi Tebing

Kearifan lokal masyarakat yang ada saat ini maupun yang menjadi peninggalan dari masa terdahulu memberikan warna tersendiri bagi wisata. Wisatawan tidak hanya disajikan artefak arkeologi, tetapi juga pengetahuan dan pengalaman. Pada tapak Candi Gunung Kawi, candi dan ceruk pertapaan dipahat langsung pada tebing alami. Proses pemahatan langsung pada dinding tebing memerlukan penguasaan pengetahuan dan teknologi membuat bangunan (arsitektur) yang tinggi. Penyesuaian harus dilakukan para pemahat dengan lokasi yang relatif sulit. Dalam hal tata guna lahan dan pemanfaatan lahan, masyarakat Bali pada masa itu mampu memilih lokasi yang tepat untuk digunakan sebagai lokasi bangunan suci. Tebing yang dipahat juga merupakan tebing dengan batuan yang kuat dan tidak hancur berabad-abad lamanya. Ceruk pertapaan digunakan sebagai tempat pelaksanaan pendidikan yang disebut asrama/pasraman. Kearifan lingkungan dapat dilihat dari adanya saluran air yang dipahat pada samping candi. Saluran air ditujukan untuk upaya penanggulangan kerusakan bangunan candi dari kikisan air dan berimplikasi bagi ketersediaan sumber daya air (Gambar 2). Air yang keluar dari tebing dialirkan melalui selokan di depan candi kemudian ditampung dalam kolam dan dialirkan ke sungai Pakerisan. Oleh masyarakat sekitar, air sungai Pakerisan digunakan untuk mengaliri persawahan yang berada di sekitar hilir sungai (Laksmi et al, 2011). 


\subsubsection{Kondisi dan Kepekaan Visual}

Salah satu hal penting yang mendukung pengembangan suatu kawasan untuk wisata adalah visual. Dalam bidang ilmu arsitektur lansekap, visual menjadi salah satu faktor yang menentukan pengembangan tapak dan memberi nilai ekonomi tinggi bagi suatu tapak. Idealnya, dalam perencanaan dan pengelolaan lansekap kajian visual penting untuk dilakukan selain kajian mengenai biofisik dan sosial budaya. Titik visual yang menarik dikembangkan dan difasilitasi, sedangkan titik visual yang buruk diberi screen (penghalang).

Candi Gunung Kawi memiliki banyak titik dengan kualitas visual lansekap yang baik. Hasil penelitian Mahaputra (2014), terdapat 12 titik dengan hasil foto yang dinilai baik oleh responden ahli. Foto-foto tersebut memiliki kualitas visual baik, karena memenuhi kriteria berikut: 1) mudah dimengerti ketika seseorang melihatnya, 2) mengandung rekaman cerita yang dapat memberikan informasi secara lugas, 3) memiliki kesan tertentu yang dapat menggambarkan kedalaman dimensi, dan 4) tidak keluar konteks. Titik-titik tersebut dapat dilihat pada Gambar 3.

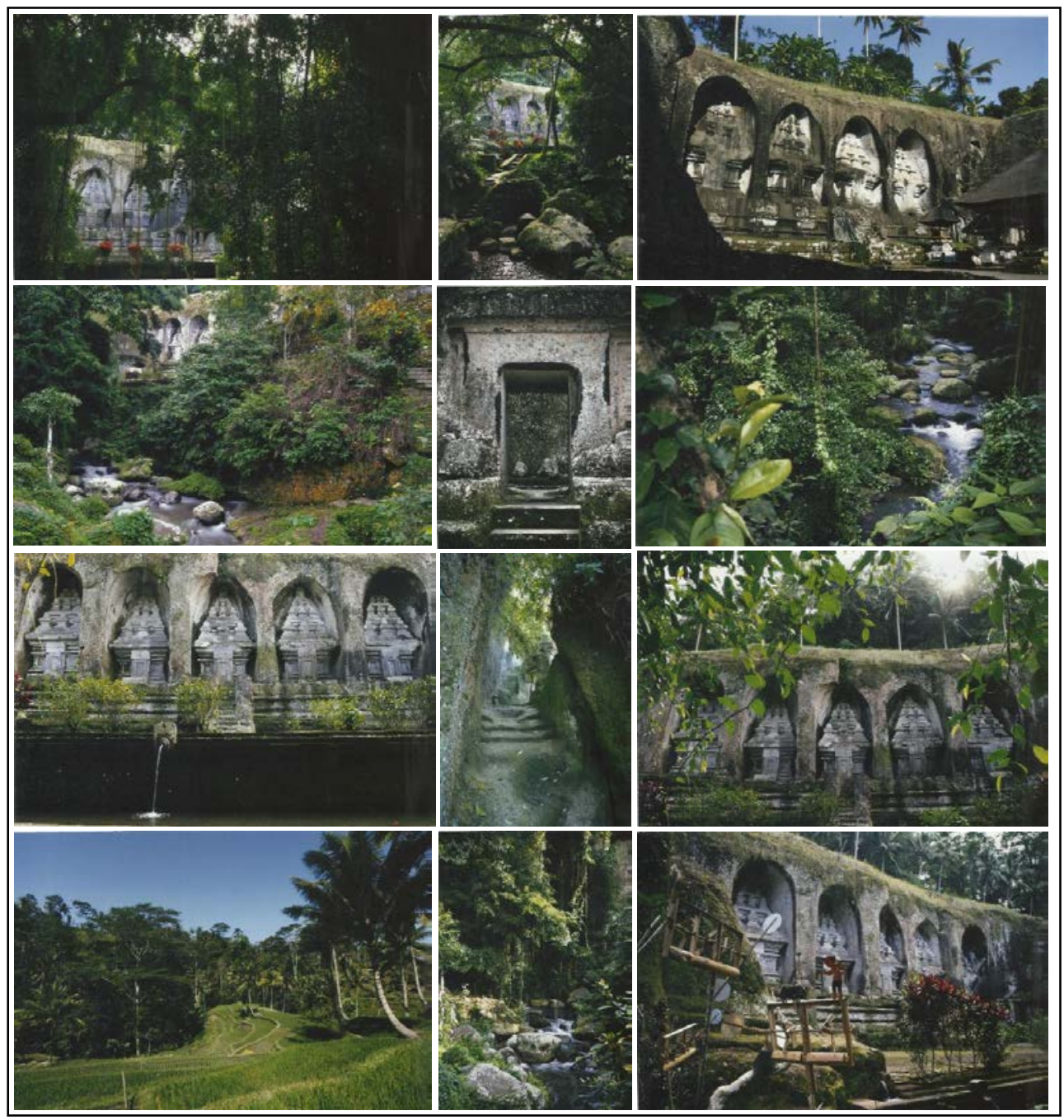

Gambar 3. Dua Belas Visual Terbaik Tapak Candi Gunung Kawi

(Sumber: Mahaputra, 2014) 


\subsection{Potensi Wisata}

Kecamatan Tampaksiring sebagai daerah tujuan wisata mengalami peningkatan jumlah pengunjung setiap tahunnya. Situs Gunung Kawi memiliki pengaruh dalam peningkatan kunjungan wisatawan ini. Pada tahun 2011 terdapat 68.070 pengunjung dan ditahun 2013 meningkat menjadi 115.795 pengunjung. Hal ini disebabkan mulai dikenalnya Situs Gunung Kawi sebagai destinasi kunjungan wisata bagi industi wisata domestik dan internasional. Peningkatan kunjungan wisata di Kecamatan Tampaksiring belum diikuti dengan peningkatan beberapa sektor usaha di bidang akomodasi wisata. Jumlah investasi bagi pengembangan hotel tidak mengalami peningkatan yaitu 5 buah. Sedangkan jumlah artshop mengalami penuruan dari 340 ditahun 2011 berkurang menjadi 336 di tahun 2013 (BPS Kabupaten Gianyar, 2014). Pendapatan sektor wisata dari penyediaan fasilitas pendukung wisata masih rendah. Peningkatan fasilitas akomodasi wisata dilakukan dengan memberikan kesempatan bagi masyarakat lokal atau desa adat menyediakan penginapan sederhana (home stay) bagi wisatawan dengan fasilitas standar internasional. Hal ini memerlukan arahan dari pemerintah untuk memberikan sosialisasi tentang fasilitas standar akomodasi. Penurunan jumlah artshop disebabkan jumlah yang terlalu banyak dan tidak menyajikan keunikan produk antara satu dengan yang lainnya. Pengembangan produk hendaknya menjadi perhatian pengelola wisata dengan berinovasi dan berkerasi terhadap produk olahan lokal. Hasil inovasi dan kreasi tersebut disosialisasikan kepada masyarakat melalui pelatihan. Dengan demikian, diharapkan masyarakat lokal mampu meningkatkan kreativitasnya dalam mengelola produknya.

Peningkatan di sektor penyediaan fasilitas pendukung wisata mengalami peningkatan pada jumlah rumah makan/restoran. Pada tahun 2011 terdapat 70 rumah makan/restoran sedangkan di tahun 2013 meningkat menjadi 73 rumah makan/restoran (BPS Kabupaten Gianyar, 2014). Hal ini mengisyaratkan kecenderungan berkembangnya wisata kuliner sebagai alternatif wisata yang mulai diminati di Kecamatan Tampaksiring, sehingga dapat menjadi salah satu destinasi wisata kuliner di Bali.

\subsection{Perencanaan Wisata Tapak Arkeologi}

Aspek utama yang harus dikelola dalam rencana zonasi untuk pengembangan kawasan wisata tapak arkeologi ini adalah 1) Kondisi ekologi tapak arkeologi, 2) Kondisi budaya masyarakat setempat, 3) Kondisi visual bentang alam atau lansekap, 4) Konsep penataan ruang, dan 5) Pengembangan masing-masing ruang. Jika seluruh aspek ini tidak direncanakan dan dikelola dengan baik, maka pemanfaatan tapak menjadi tidak teratur dan mempengaruhi kondisi ekologis dan visual tapak dalam jangka panjang. Dampak yang terjadi dapat dilihat dari vandalisme dan kerusakan benda arkeologi, bertumpuknya sampah, bertumpuknya pengunjung pada beberapa tempat, pengunjung menjadi tidak terarah, dan kemacetan tidak bisa dihindarkan.

Penataan ruang tapak (zonasi) pada tapak arkeologi perlu memperhatikan kelestarian benda arkeologi. Seperti halnya pada cagar budaya yang tertuang dalam Undang-undang Nomor 11 Tahun 2010 tentang cagar budaya. Sistem zonasi mengatur fungsi ruang pada cagar budaya dan terdiri atas a) zona inti, b) zona penyangga, c) zona pengembangan, dan d) zona penunjang. Zona inti merupakan area perlindungan utama 
untuk menjaga bagian dari situs cagar budaya dan/atau kawasan cagar budaya yang mengandung benda cagar budaya, bangunan cagar budaya, dan struktur cagar budaya yang paling penting. Zona penyangga merupakan area yang melindungi zona inti. Zona pengembangan merupakan area yang diperuntukan bagi pengembangan potensi cagar budaya untuk kepentingan rekreasi, konservasi, konservasi lingkungan alam, lansekap budaya, kehidupan budaya tradisional, keagamaan dan kepariwisataan. Zona penunjang merupakan area yang diperuntukkan bagi penempatan sarana dan prasarana penunjang untuk mendukung kegiatan usaha dan/atau rekreasi umum.

Selain memperhatikan zonasi bagi pelestarian tapak arkeologi, lebih jauh dapat ditinjau budaya masyarakat setempat. Budaya memiliki makna yang kuat terhadap ruang. Masyarakat menggunakan ruang dengan fungsinya masing-masing. Perencanaan tata ruang wisata yang dikelola berdasarkan pemanfaatan ruang oleh masyarakat sekitar akan mempermudah masyarakat untuk dapat beradaptasi dengan ruang wisata sehingga konflik dapat terhindarkan. Masyarakat Bali membagi ruang berdasarkan konsep tata ruang di Bali yang disebut tri mandala. Konsep tersebut terlahir dari kebutuhan masyarakat Bali terhadap ruang-ruang yang spesifik. Konsep tata ruang Bali hendaknya diperhitungkan dalam menata ruang wisata pada tapak arkeologi di Bali.

Konsep ruang yang dikembangkan pada tapak Candi Gunung Kawi, dapat mengkolaborasikan bentuk penataan ruang berdasarkan penataan ruang bagi cagar budaya dan penataan ruang yang menjadi kearifan lokal masyarakat Bali, yaitu tri mandala. Penataan ruang tersebut dapat dibagi menjadi 3 ruang yaitu ruang pelestarian, ruang penyangga, dan ruang pemanfaatan wisata (Gambar 4). Ruang pelestarian merupakan perwujudan dari ruang inti pada cagar budaya dan ruang utama-mandala pada tri mandala. Ruang ini merupakan ruang perlindungan bagi benda arkeologi maupun cagar budaya dan hanya berfungsi terbatas untuk kegiatan tertentu yang dimanfaatkan oleh masyarakat lokal. Pada Candi Gunung Kawi lokasi ini terdiri atas candi dan ruang pertapaan yang fungsinya sangat terbatas, seperti untuk kegiatan upacara oleh masyarakat lokal dan kegiatan pelestarian yang perlu dilakukan oleh arkeologis yang berwenang. Ruang penyangga merupakan perwujudan dari zona penyangga pada cagar budaya dan ruang madya-mandala pada tri mandala. Ruang ini berfungsi sebagai ruang penyangga dari kegiatan yang ada di ruang inti. Ruang ini digunakan terbatas untuk penelitian dan studi, serta terbatas pada hal-hal yang terkait perlindungan yang dilakukan oleh pihak berwenang. Terakhir adalah ruang pemanfaatan wisata yang merupakan perwujudan dari zona pengembangan dan zona penunjang pada cagar budaya dan ruang kanista-mandala pada tri mandala. Ruang ini dimanfaatkan untuk wisata dan kegiatan lain penunjang kegiatan wisata. Wisata yang sebaiknya dikembangkan adalah wisata edukasi. Wisata edukasi dapat memberi banyak manfaat bagi pengunjung. Pengunjung dapat diberikan pemahaman terhadap nilai tapak arkeologi dan pentingnya pelestarian tapak arkeologi.

Konsep ini juga mengadaptasi konsep tri hita karana. Konsep tersebut dapat dilihat pada perwujudan parahyangan yang dilakukan pada ruang inti atau ruang pelestarian dengan aktivitas terkait hubungan manusia dengan Tuhan dengan tetap mengfungsikan 
candi sebagai tempat peribadatan. Palemahan diwujudkan pada ruang penyangga dengan aktivitas terkait penunjang pelestarian baik secara biofisk, sosial budaya, maupun visual. Pada ruang ini masyarakat tetap dapat melakukan aktivitas sehari-hari seperti bertani dan melakukan kegiatan keseharian. Ruang ini juga tetap dipertahankan fungsinya bagi kelestarian lingkungan. Dan terakhir, perwujudan pawongan, yaitu adanya hubungan antar sesama manusia pada ruang pemanfaatan wisata. Aktivitas wisata dan aktivitas penunjang wisata akan banyak terjadi. Pada ruang ini terjadi kegiatan sosial dan ekonomi antara masyarakat lokal dan pengunjung tapak wisata Candi Gunung Kawi.

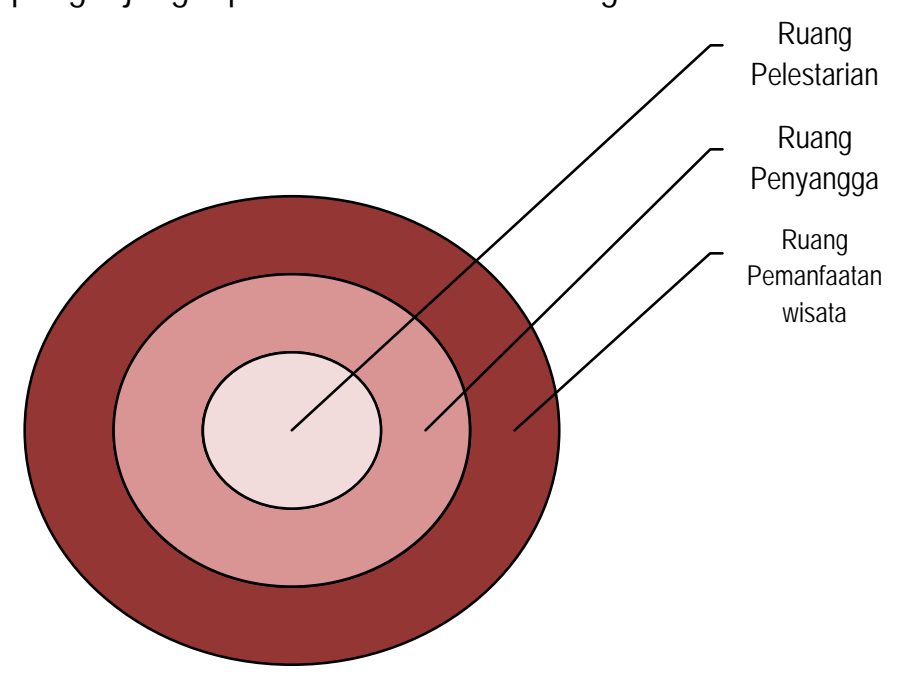

Gambar 4. Konsep penataan ruang wisata pada tapak arkeologi Candi Gunung Kawi

\subsection{Program Interpretasi Wisata Budaya}

Rencana program interpretasi ditujukan untuk mengelola aktivitas wisata agar dapat sejalan dengan tujuan dan pesan yang akan disampaikan. Aktivitas wisata tersebut hendaknya dapat memberikan pengetahuan dan pengalaman baru bagi pengunjung (Alderson dan Low, 1996). Program interpretasi tapak Candi Gunung Kawi yang sesuai adalah program interpretasi wisata berbasis edukasi artinya kegiatan wisata lebih mengarah pada kegiatan yang mampu mengedukasi pengunjung tentang kawasan sejarah budaya. Kepuasan pengunjung nantinya yang menjadi tolok ukur keberhasilan program interpretasi wisata yang direncanakan.

Candi Gunung kawi merupakan tapak peninggalan sejarah yang berfungsi sebagai tempat menimba ilmu pada masa itu. Tapak ini memiliki ceruk pertapaan yang dahulu dijadikan sebagai tempat merenung bagi para cendekia. Di samping itu, tapak ini juga memperlihatkan tingkat penguasaan teknologi yang tinggi di masa itu dan memiliki kearifan lokal dalam menata dan mengelola lingkungan. Interpretasi wisata pada tapak dikembangkan mengikuti pola jalur sirkulasi yang sudah ada dan dikembangkan dengan menonjolkan keindahan alam (good view) di sepanjang jalur jalan tersebut. Pahatan candi dan ceruk pertapaan menjadi wisata inti. Linkungan alami, suasana pedesaan, dan aktivitas pertanian menjadi obyek potensial yang dapat dikembangkan. 
Pengembangan interpretasi dapat meminimalisir kerusakan tapak dan benda arkeologi akibat aktivitas pengunjung yang tidak bertanggung jawab dengan adanya pemandu wisata yang dapat menjelaskan makna tapak arkeologi. Selain itu, pemberian papan informasi juga penting untuk dapat memberi informasi yang jelas bagi pengunjung tentang makna dan nilai benda arkeologi, serta kearifan lokal yang ada. Tanda larangan juga dapat disertakan agar pengunjung mengetahui apa yang dapat atau tidak dapat dilakukan oleh pengunjung ketika berada dalam tapak. Penataan jalur jalan perlu disertai dengan pemberian batas pada benda arkeologi agar tidak disentuh, dinaiki, vandalisme, atau dirusak oleh pengunjung. Fasilitas bagi pengunjung disediakan untuk dapat mengabadikan momen kunjungannya berupa bangku taman atau stage untuk lokasi foto dan titik pengambilan foto terbaik. Penyediaan fasilitas ini dapat meminimalisir kerusakan akibat pengunjung yang ingin mengambil foto. Media interpretasi yang disediakan diharapkan dapat melakukan transfer informasi sehingga nilai edukasi dapat dirasakan oleh pengunjung dan kerusakan serta pengurangan nilai benda arkeologi dapat diminimalisir.

\section{Simpulan}

Pengembangan tapak arkeologi untuk wisata memerlukan kajian mengenai kondisi fisik tapak, kondisi sosial budaya masyarakat sekitar, dan kajian visual tapak untuk melihat berbagai potensi tapak untuk wisata. Semua aspek ini menjadi potensi tapak sekaligus menjadi faktor pembatas bagi pengembangan tapak. Pengembangan tapak arkeologi di Candi Gunung Kawi untuk tujuan wisata budaya diarahkan pada pengembangan wisata edukasi untuk dapat memberi pengetahuan tentang budaya dan kearifan lokal masyarakat dan memberi pemahaman tetang pentingnya pelestarian tapak arkeologi.

Perencanaan tapak arkeologi bagi pengembangan wisata di Candi Gunung Kawi menghasilkan konsep yang memadukan antara zonasi pada cagar budaya dan konsep Tri Mandala dan Tri Hita Karana yang merupakan kearifan lokal masyarakat Bali. Penataan ruang yang dikembangkan tersebut terdiri atas ruang pelestarian, ruang penyangga dan ruang pemanfaatan wisata.

Program interpretasi yang dikembangkan berupa program edukatif yang dapat menyampaikan pesan bagi pengunjung tentang makna tapak arkeologi tersebut bagi masyarakat lokal dengan kearifan lokal dalam menata dan mengelola lingkungan. Pemandu wisata dan fasilitas wisata berperan dalam mendukung transfer ilmu dan pelestarian tapak arkeologi.

\section{Daftar Pustaka}

Alderson WT, Low SP. 1996. Interpretation of Historic Sites. Second Edition, Revised. California : Altamira Press.

Badan Pusat Statistik Kabupaten Gianyar. 2014. Statistika Daerah Kecamatan Tampaksiring 2014. Denpasar : PT. Percetakan Bali. 
Chiara J de, Koppelman LE, 1978. Standar Perencanaan Tapak. Dari judul asli : Site Planning Standards, Penerbit : McGraw-Hill Inc, alih bahasa : Ir. Januar Hakim. Penerbit Erlangga, Jakarta.

Laksmi RS, Mardika IM, Sudrama K. 2011. Cagar Budaya Bali Menggali Kearifan Lokal dan Model Pelestariannya. Udayana University Press, Denpasar.

Mahaputra IGNAP. 2014. Memetakan Kualitas Visual Lansekap Pada Obyek Wisata Alam Candi Gunung Kawi Tampaksiring - Gianyar [Skripsi]. Fakultas Pertanian. Universitas Udayana. [Tidak dipublikasika].

Nurisyah S, Damayanti VD. 2006. Pengembangan Interpretasi Wisata Pesisir Guna Mendukung Program Pendidikan Sumber Daya Pesisir dan Kelautan. Di Dalam : Kumpulan Riset Kelautan: Jalan Menuju Kejayaan Bahari. Bogor: Bakosurtanal. 